Zeszyty Naukowe Szkoły Głównej Gospodarstwa Wiejskiego

Ekonomika i Organizacja Gospodarki Żywnościowej nr 111, 2015: 43-60

Hanna Górska-Warsewicz, Monika Świątkowska

Katedra Organizacji i Ekonomiki Konsumpcji

Szkoła Główna Gospodarstwa Wiejskiego w Warszawie

\title{
Marketingowe determinanty wprowadzania na rynek nowych produktów w przedsiębiorstwach sektora zbożowego
}

\section{Wstęp}

Natężenie działań konkurencyjnych na rynku produktów zbożowych determinuje decyzje w kierunku udoskonalania dotychczas oferowanych produktów oraz poszukiwanie nowych rozwiązań w zakresie technologii produkcji, składu produktu, jego właściwości, sposobu opakowania itp. Produkt innowacyjny jest rezultatem procesu obejmującego wszystkie działy przedsiębiorstwa łącznie z gruntowną analizą potrzeb i preferencji konsumenckich. Sukces rynkowy nowych produktów wynika z umiejętnej kompilacji szeregu uwarunkowań, włączając czynniki technologiczne, organizacyjne oraz marketingowe. Te ostatnie należy uznać w dobie dzisiejszej za kluczowe w przypadku produktów cechujących się - z jednej strony - zróżnicowaniem asortymentowym i technologicznym, z drugiej - postrzeganych przez większość konsumentów w kategoriach rodzajowych.

Celem niniejszego opracowania była analiza wybranych uwarunkowań marketingowych determinujących wprowadzanie na rynek nowych produktów w przedsiębiorstwach sektora zbożowego, ze szczególnym uwzględnieniem działań promocyjnych i marki. Całość osadzono w realiach procesu rozwoju nowych produktów i dokonaniu przeglądu literatury dotyczącej działań promocyjnych i marki.

\section{Materiały i metodyka badań}

Badania empiryczne stanowiące podstawę analizy niniejszego opracowania zrealizowano w listopadzie i grudniu 2013 roku w ramach projektu POIG.01-14-041/12 współfinansowanego z Europejskiego Funduszu Rozwoju Regionalne- 
go w ramach Programu Operacyjnego Innowacyjna Gospodarka „Bioprodukty, innowacyjne technologie wytwarzania prozdrowotnych produktów piekarskich i makaronu o obniżonej kaloryczności” w zadaniu nr 1 „Analiza rynku produktów zbożowych i zachowań konsumentów". W ramach projektu przeprowadzono dedykowane badanie terenowe realizowane metodą wywiadów telefonicznych ze wspomaganiem komputerowym (Computer Assisted Telephone Interview, czyli wspomagany komputerowo wywiad telefoniczny) z wykorzystaniem standaryzowanego kwestionariusza wywiadu. Kwestionariusz wywiadu obejmował pytania dotyczące: dostawców surowców i półproduktów, oczekiwań producentów rolnych (dostawców surowców), źródeł pochodzenia surowców do przetwórstwa preferowanych przez przedsiębiorstwo przetwórstwa zbóż, uwarunkowań marketingowych determinujących rozwój nowych produktów, oczekiwań przedsiębiorstw przetwórstwa zbóż wobec dostawców w zakresie wiedzy rolniczej itp. W niniejszym opracowaniu wykorzystano część wyników w zakresie marketingowych uwarunkowań wprowadzania na rynek nowych produktów w przedsiębiorstwach sektora zbożowego.

Próbę badawczą stanowiło 200 przedsiębiorstw dobranych według kryterium wielkości przedsiębiorstw. Zastosowano następującą strukturę przedsiębiorstw: mikroprzedsiębiorcy $20 \%$, mali przedsiębiorcy $30 \%$, średni przedsiębiorcy $30 \%$ i duże przedsiębiorstwa $20 \%$.

Przyjęto definicje mikroprzedsiębiorcy, małego i średniego przedsiębiorcy zgodnie z ustawą z dnia 2 lipca 2004 roku o swobodzie działalności gospodarczej (Dz.U. z 2004 r. nr 173, poz. 1807, ostatnio zmieniony w Dz.U. z 2012 r. nr 0, poz. 1529, tekst jednolity: Dz.U. z 2013 r. nr 0, poz. 672).

W opracowywaniu założeń metodycznych do badania przyjęto nazewnictwo zgodnie z klasyfikacją Głównego Urzędu Statystycznego. Produkty zbożowe to ryż, pieczywo, krakersy, suchary, makaron, produkty makaronowe, mąka, wyroby ciastkarskie, pizze, kanapki, kasze, płatki, półprodukty mączne. W kategorii „pieczywo" uwzględniono wszystkie gatunki i rodzaje pieczywa bez wyrobów ciastkarskich. Skład grupy produktowej ,wyroby ciastkarskie” jest stosunkowo szeroki i obejmuje wyroby z ciasta drożdżowego, francuskiego, parzonego, kruchego, biszkoptowego, z masy orzechowej, migdałowej, pieczywo cukiernicze trwałe (wafle, pierniczki), drożdżowe, piankowe, pozostałe.

\section{Teoria dotycząca promocji i marki}

Sukces rynkowy w przypadku produktów zbożowych i ich przetworów, przy zmieniających się warunkach rynku i nowych potrzebach konsumentów, w dużym stopniu opiera się na skutecznej komunikacji rynkowej. Podstawą skutecznych i efektywnych działań komunikacyjnych na rynku produktów zbożo- 
wych jest dobór odpowiednich narzędzi komunikacji rynkowej, zintegrowanych $\mathrm{w}$ formie strategii promocyjnej oraz wobec marki produktu, precyzyjne określenie segmentów docelowych, a następnie skierowanie do nich narzędzi mieszanki promocyjnej (promotion mix), opracowanej przy wykorzystaniu badań rynkowych, doświadczeń uczestnictwa na konkretnym rynku produktowym, wsparcia ekspertów i innych działań.

Strategia promocji może być zdefiniowana jako zaplanowany sposób osiągnięcia celów organizacji przez wybór określonych instrumentów promocji oraz sposobu ich zastosowania w odniesieniu do produktów lub całego przedsiębiorstwa. Podstawowym celem każdej strategii promocyjnej jest oddziaływanie na wielkość sprzedaży (przedsiębiorstw i sektora); jej efektem może być jednak również zmiana wizerunku produktu, producenta czy marki w świadomości konsumenta, a także tworzenie i wzmocnienie lojalności konsumentów wobec produktu. Promocja może także neutralizować skutki działań konkurencji, ujawniać ważne informacje dla wizerunku sektora (np. produktów zbożowych); pełni też istotną rolę edukacyjną, zwłaszcza na rynku żywności. Wymienione funkcje strategii promocji w odniesieniu do sektora, są często ważniejsze niż jednorazowe nakłonienie konsumenta do zakupu [Kall 2002, s. 63].

Przedsiębiorstwo może stosować jednocześnie kilka różnych strategii komunikacji marketingowej, np. w zależności od produktu (grupy produktów) lub odbiorcy (grupy odbiorców), dzięki czemu zyskuje efekt synergii (wzmocnienia komunikatu, np. dotyczącego marki lub firmy). Przy braku integracji strategii mogą wystąpić sprzeczności między nimi, np. strategia aktywizacji może wpływać negatywnie na strategię wizerunkową [Czarnecki 2004, s. 182].

Do najważniejszych czynników wpływających na strategię promocji (jako elementu strategii marketingowej) stosowaną przez przedsiębiorstwo można zaliczyć [Czarnecki 2004, s. 182-183]:

- cykl życia produktu, rodzaj produktu i charakter (osobowość) marki,

- strategie komunikacji stosowane na rynku i przez konkurentów rynkowych,

- wielkość przedsiębiorstwa i posiadane zasoby, jego pozycję rynkową, rodzaj konkurencji,

- fazę rozwojową i formę rynku,

- rodzaj nabywcy,

- politykę dystrybucji.

W przypadku produktów i przetworów zbożowych, najważniejszą rolę w strategiach promocji odgrywa najczęściej sam produkt i jego charakterystyka (żywieniowa, funkcjonalna, rynkowa). Związki promocji z produktami zbożowymi można rozpatrywać w odniesieniu do ich rodzajów, charakterystyki oraz cyklu życia. Zwłaszcza ten ostatni czynnik wywiera znaczący wpływ na kształtowanie polityki promocyjnej przedsiębiorstwa w dwojaki sposób: wpływa na 
jej natężenie (intensywność), a także decyduje o doborze konkretnych środków promocji w czasie jej trwania [Kramer 2004, s. 138].

Intensywność działań promocyjnych jest relatywnie największa $\mathrm{w}$ fazie wprowadzania produktu na rynek, kiedy ma za zadanie spełnienie funkcji informacyjnych, rozszerzenie kręgu kupujących i szybkie dotarcie do segmentu wczesnych naśladowców i wczesnej większości, a także zakupy na próbę. W fazie wzrostu natężenie promocji ulega pewnemu osłabieniu, aby zyskać na znaczeniu w końcowej fazie życia produktu na rynku. W stadium wprowadzania i wzrostu jest wykorzystywana przede wszystkim reklama, która poprzez swoje funkcje informacyjne kształtuje potrzeby; na późniejszych etapach coraz większego znaczenia nabiera promocja sprzedaży [Wiktor 2006, s. 66].

Pozycja rynkowa przedsiębiorstwa i rodzaj rynku warunkują możliwości i zasadność prowadzenia działań z zakresu komunikacji marketingowej i określają jej cele, które wiążą się ze stosowaną strategią promocji. Przedsiębiorstwa duże, o dominującej pozycji na rynku (np. Grupa Maspex, Nestle), w celu poprawy wizerunku mogą wykorzystywać intensywne działania o charakterze PR i sponsoring, a w celu zwiększenia poziomu sprzedaży - działania informacje lub aktywizujące. Strategie wykorzystywane przez te przedsiębiorstwa mają na celu podtrzymywanie lub wzmacnianie tożsamości marek oraz przekonywanie o ich wyższości nad markami konkurencyjnymi. Są to przede wszystkim kampanie wizerunkowe (stosowane przez liderów rynkowych, wykorzystujące głównie reklamę oraz promocję sprzedaży). $\mathrm{W}$ warunkach rynków rozproszonych, jak rynek mąki, kaszy czy pieczywa, strategie marketingowe firm są zbliżone i brak w nich zintegrowanego podejścia do komunikacji marketingowej, a poszczególne ich elementy są stosowane doraźnie; znajdują tu zastosowanie takie formy promocji jak promocja sprzedaży (w postaci upustów cenowych i cen promocyjnych), sponsoring czy programy lojalnościowe.

Dużą rolę w promocji produktów na rynku produktów i przetworów zbożowych odgrywa też wielkość przedsiębiorstwa, która warunkuje wysokość budżetu przeznaczonego na komunikację marketingową. Przedsiębiorstwa sektora zbożowego różnią się zasobami kapitałowymi, technicznymi, organizacyjnymi i ludzkimi, które warunkują w dużym stopniu potencjalne możliwości stosowania różnorodnych strategii marketingowych i strategii promocji. Na strategię taką wpływa także rodzaj stosowanej przez nie konkurencji (konkurencja cenowa wymusza wykorzystanie innych strategii komunikacyjnych niż konkurencja oparta na jakości) oraz strategie konkurencji stosowane przez liderów rynkowych, które mogą obniżać skuteczność własnych strategii przedsiębiorstwa i wymuszać wykorzystanie strategii wpływających na ograniczenie efektów strategii konkurentów. 
Strategie komunikacji marketingowej przedsiębiorstw sektora produktów i przetworów zbożowych w segmentach opartych o kreowanie i wspieranie produktów markowych (produktów wyżej przetworzonych i o większej wartości dodanej, takich jak płatki zbożowe czy makarony), z punktu widzenia realizowanych celów można podzielić na strategie [Czarnecki 2004, s. 180]:

- informacyjne (informujące o nowych produktach), które dotyczą głównie produktów nowo wprowadzanych na rynek albo innowacji produktowych (np. wprowadzanych w 2013 roku na rynek makaronów firmy Barilla);

- aktywizujące (wzbudzające zainteresowanie produktem i zachęcające do jego nabycia), np. kampanie reklamowe produktów znajdujących się w fazie dojrzałości rynkowej (np. kampanie promocyjne makaronów, pieczywa czy płatków);

- nakłaniające (komunikujące elementy przewagi konkurencyjnej i nakłaniające do zakupu), dotyczące produktów, na rynku których panuje duża konkurencja (np. makaronów);

- budujące lojalność (więź i relacje z klientem) na rynku produktów zbożowych stosowane przede wszystkim $\mathrm{w}$ odniesieniu do produktów markowych;

- wizerunkowe (kształtujące lub zmieniające wizerunek), związane $\mathrm{z}$ dywersyfikacją albo zmianą strategii marketingowej tych firm. Podobnie jak w przypadku kampanii wizerunkowych, są one stosowane przede wszystkim w odniesieniu do produktów markowych; istnieje jednak również możliwość kształtowania wizerunku kategorii produktu (np. pieczywa, mąki, kaszy).

Biorąc pod uwagę instrumenty komunikacji marketingowej i zasięg ich działania, przedsiębiorstwa sektora produktów i przetworów zbożowych przyjmują strategie [Rydel 2001, s. 29]:

- komunikacji masowej na rynku (z wykorzystaniem mediów masowych, o szerokim zasięgu, takich jak telewizja, prasa, radio, outdoor), które stosowane są tylko przez duże przedsiębiorstwa sektora posiadające produkty markowe (np. makaronów Lubella, płatków Nestle);

- komunikacji zindywidualizowanej, stosowane w kanałach dystrybucji w niektórych segmentach produktów zbożowych (takich jak mąka czy kasza), zakładające bezpośredni kontakt z klientami, zindywidualizowanie oferty i relacji opartych na lojalności z wykorzystaniem zwłaszcza marketingu bezpośredniego;

- komunikacji bezpośredniej, w odniesieniu do rynkowych segmentów generycznych sektora (jak np. pieczywo), z wykorzystaniem promocji w miejscu sprzedaży, w tym promocji cenowych; 
- pośrednie, wykorzystujące różne formy komunikacji ze wszystkich grup (kombinacja promocji masowej, ATL i BTL), która dotyczy wielu przedsiębiorstw sektora i jest dostosowana do ich specyfiki i sytuacji rynkowej.

Ze względu na liczbę instrumentów wykorzystywanych w komunikacji marketingowej, przedsiębiorstwa sektora produktów i przetworów zbożowych można podzielić na wykorzystujące pojedyncze instrumenty komunikacji (monoinstrumentalne) i kilka instrumentów komunikacji rynkowej (wieloinstrumentalne). Pierwsze opierają się na jednym głównym i dominującym instrumencie komunikacji marketingowej (np. reklamie czy promocji sprzedaży), drugie wykorzystują kilka instrumentów jednocześnie (reklamy, PR, promocje sprzedaży, promocje cenowe), co umożliwia uzyskanie efektu synergii i większej efektywności procesu komunikacji marketingowej. Przykładowo, w strategiach komunikacji marketingowej na rynku pieczywa dominuje promocja sprzedaży (wsparta promocją cenowa), a w przypadku segmentu płatków zbożowych liderzy rynku preferują reklamę.

Zaawansowana postacią strategii wieloinstrumentalnych jest zintegrowana komunikacja marketingowa (ZKM) $)^{1}$, w ramach której firmy starannie integrują i koordynują liczne narzędzia i kanały komunikacyjne, aby dostarczyć jasnego i spójnego oraz przekonującego przesłania dotyczącego oferowanych produktów, a także samego przedsiębiorstwa [Kotler i in. 2002, s. 851]. Na zintegrowaną komunikację marketingową składają się takie elementy jak rozpoznanie elementów przewagi konkurencyjnej firmy (traktowanych priorytetowo), identyfikacja najważniejszych odbiorców tych komunikatów, planowanie działań z zakresu komunikacji marketingowej, nadzór nad procesem komunikacji (jakością i ilością komunikatów wychodzących z firmy) i kontrola jego efektów, będąca podstawą do korygowania planów promocji [Rydel 2001, s. 20]. Zastosowanie koncepcji zintegrowanej komunikacji marketingowej ma spowodować, aby wszystkie działania marketingowe przekazywały do otoczenia rynkowego jednolity, zwarty obraz oferty produktowej i samej firmy [Belch i Belch 1995, s. 8]. Działania z zakresu ZKM są formą oddziaływania przedsiębiorstw na różne grupy odbiorców rynkowych, partnerów organizacji (a nie tylko klientów) w kanałach dystrybucji, elementem zarządzania dialogiem firmy z jej wewnętrznymi (pracownikami, związkami zawodowymi) i zewnętrznymi klientami (dostawcami, pośrednikami, mediami, konkurentami, opinią publiczną) [Kowalska 2007, s. 67-68].

Ważnym elementem uwarunkowań marketingowych związanych z rozwojem nowych produktów są decyzje przedsiębiorstw wobec marki. Natężenie

\footnotetext{
${ }^{1}$ Szerzej w: H. Górska-Warsewicz, Świątkowska M., Krajewski K., Model zintegrowanej komunikacji rynkowej. Aspekty zarzqdzania produktem i marka na rynku żywności, Wyd. SGGW, Warszawa 2009; Świątkowska M., Górska-Warsewicz H., Krajewski K., Zarzqdzanie komunikacja rynkowq przedsiębiorstw - organizacja, strategie, uwarunkowania, Wyd. SGGW, Warszawa 2010.
} 
działań konkurencyjnych determinuje stosowanie zróżnicowanych strategii nazewnictwa nawet $\mathrm{w}$ odniesieniu do takich kategorii produktowych jak produkty zbożowe.

Marka $^{2}$ definiowana jest jako „nazwa, termin, symbol bądź projekt graficzny lub ich kombinacja, których celem jest identyfikowanie towarów i usług jednego sprzedawcy lub grupy sprzedawców oraz ich odróżnienie od towarów lub usług oferowanych przez konkurencję" ${ }^{3}$. Należy wskazać, że z jednej strony marka jest prostą ideą wskazującą na nazwę, logo, symbol, tożsamość lub znak handlowy. Z innej perspektywy - analizowanej coraz częściej - znajduje się kompleksowa idea i kompozycja wielu elementów materialnych i niematerialnych. W najbardziej złożonym ujęciu marka jest obietnica, pewną cechą charakterystyczna, zapewnieniem kupującego, także zestawem skojarzeń lub oczekiwań oraz wizerunkiem powodującym, że konsumenci kupują produkty opatrzone daną marką. Należy więc traktować markę jako symbol będący podstawą tworzenia relacji między firmą i jej produktami a konsumentami ${ }^{4}$.

Dokonując kwerendy literatury wyróżnić można dwie grupy definicji marki. Pierwsza odnosi się do marki jako sumy produktu oraz pewnej dodatkowej wartości z nim związanej, druga natomiast odzwierciedla „określoną wartość dodaną do produktu bez uwzględniania samego produktu. $Z$ kolei definicja węższa marki traktuje markę jako identyfikator w kontekście nazwy, terminu, znaku, symbolu lub ich kombinacji, mających na celu identyfikację wyrobu lub usługi oraz ich odróżnienie od oferty konkurentów”. Szersza perspektywa ujmuje markę jako zestaw korzyści dla jej użytkownika i odnosi się do marki jako „,zespołu funkcjonalnych, ekonomicznych i psychologicznych korzyści dla użytkownika, których dostarcza produkt oznaczony odpowiednim identyfikatorem" [Urbanek 2002, s. 14-15].

Jeden z najszerszych opisów marki wskazuje na trzy obszary interpretacji. Pierwszy dotyczy marki jako narzędzia zarządzania i obejmuje logo, instrument prawny, firmę, zapis stenograficzny, czynnik ograniczający ryzyko,

\footnotetext{
${ }^{2}$ Szerzej w H. Górska-Warsewicz, Ksztaltowanie architektury marek przedsiębiorstw sektora żywnościowego, Wyd. Difin, Warszawa 2011; H. Górska-Warsewicz, Konsumencki kapitat marek produktów na potrzeby zarzadzania przedsiębiorstwem (na przyktadzie sektora mleczarskiego), Wydawnictwo Naukowe Wydziału Zarządzania Uniwersytetu Warszawskiego, Warszawa 2011.

${ }^{3}$ Dictionary of Marketing Terms, AMA Chicago 1995, s. 18 cyt. za J. Altkorn: Strategiamarki, PWE, Warszawa 1999, s. 11; L. de Chernatony 2003: Marka. Wizja i tworzenie marki, GWP, Gdańsk, s. 34; Ph. Kotler: Marketing, Dom Wydawniczy Rebis, Poznań 2005, s. 421.

${ }^{4}$ L. Leuthesser, 1998: Defining, Measuring, and Managing Brand Equity, Conference Summary (Cambridge, MA: Marketing Science Institute), s. 2; K.L. Keller, 1993: Conceptualizing, measuring and managing customer-based brand equity, Journal of Marketing 57, 1-22, s. 4; R.K. Srivastava, A. Shocker, 1991: Brand Equity: A Perspective on Its Meaning and Measurement, Technical Working Paper (Cambridge, MA: Marketing Science Institute), s. 5; D.A. Aaker, 1996 Building Strong Brands, (New York: Free Press), s. 35.
} 
pozycjonowanie, osobowość, wiązkę wartości, wizję, tożsamość. Interpretacja druga wskazuje na płaszczyznę konsumenta, włączając wizerunek i jej związek z konsumentem. Interpretacja trzecia dotyczy perspektywy czasowej i prezentuje „ewolucyjny charakter marki” od marek najsłabszych do kultury i religii marki [Chernatony 2003, s. 32].

$\mathrm{W}$ ostatnich latach nastapiło przesunięcie percepcji z produktu (productfocus) na markę (brandfocus). W tym aspekcie należy postrzegać markę jako wielowymiarową konstrukcję, która integruje fizyczne i niematerialne atrybuty produktu i składa się z następujących elementów; wizerunek marki (sposób, w jaki konsumenci postrzegają markę), tożsamość marki (sposób, w jaki kreator marki chce, aby była postrzegana przez konsumentów) i pozycjonowanie marki (miejsce marki na rynku w danym momencie) [Bivainiene 2007]. Jednocześnie podkreślana jest zależność między produktem a marką. Produkt reprezentuje widzialne atrybuty, marka natomiast odzwierciedla gwarancję i zapewnia konsumentów o korzyściach wynikających z jej siły. Z marką związane są także skojarzenia wynikające z jej wizji, wartości, filozofii, charakterystyki typowego nabywcy, jego osobowości itp. Istotnym zagadnieniem jest efekt halo, stanowiący główne źródło wartości kreowanej przez markę. Należy go traktować jako efekt synergiczny wynikający ze wspólnego oddziaływania widzialnych cech produktu i niewidzialnych wartości marki. W tym aspekcie znana marka wpływa na percepcję konsumentów w zakresie atrybutów produktu, potęując efekt odbioru przekazu [Kapferer 2009, s. 41].

Całościowe podejście do marki wynika z faktu, że konsumenci postrzegaja produkty kojarząc z marką wszystkie atrybuty doświadczane przez zakup i użytkowanie produktu [Vazquez, del Rio i Iglesias 2002, s. 29]. Separowanie obu atrybutów (związanych z marką i dotyczących produktu) jest trudne ze względu na występowanie interakcji ${ }^{5}$. Marka jako „pojęcie wielopłaszczyznowe” może być rozpatrywana przez górę lodową brandingu [Dawidson 1997, s. 376]. Silna marka jest rezultatem realizowanej strategii. Koncepcja ta zakłada istnienie elementów widzialnych i niewidzialnych dla konsumentów/użytkowników, co należy analizować jako punkt widzenia budowy przewagi konkurencyjnej. W tym aspekcie ważne są elementy widzialne, odzwierciedlające podjęte przez przedsiębiorstwa decyzje w zakresie działań marketingowych oraz związanych z procesami inwestycyjnymi i alokacją środków finansowych. Elementy umieszczone poniżej tzw. poziomu wody związane są z kompetencjami, aktywami i możliwościami przedsiębiorstwa skoncentrowanymi na określonej marce.

\footnotetext{
${ }^{5}$ T. Ambler, C. Styles, 1997: Brand development versus new product development: toward a process model of extension decisions, Journal of Product and Brand Management 1997, vol. 6, No. 4, s. 222-234; C. Styles, T. Ambler, 1995: Brand management, (in:) Crainer S. (ed.) Financial Times Handbook of Management, Pitman, London s. 581-593.
} 
Analizując marki oferowane przez przedsiębiorstwa produkcyjne z sektora żywnościowego należy uznać, że markę stanowi zestaw elementów materialnych wynikających z określonej technologii produkcji (np. składu surowcowego) i opakowania w połączeniu z elementami niematerialnymi wynikającymi z przyjętych założeń producenta $\mathrm{w}$ odniesieniu do architektury marki, miejsca produktu w portfelu asortymentowym, osobowości marki, jej znajomości i możliwości oferowania wartości dodanej. Ten aspekt przedstawić można w formie piramidy, u podstawy której umieszczono względy techniczne i technologiczne. Kolejne poziomu oznaczają przejście od aspektów materialnych w percepcji marki po względy niematerialne odnoszące się do osobowości marki ${ }^{6}$.

\section{Charakterystyka badanej populacji przedsiębiorstw}

Próbę badawczą przedsiębiorstw sektora zbożowego stanowiło 200 podmiotów gospodarczych. Ich struktura pod względem wielkości kształtowała się następująco: mikroprzedsiębiorcy $20 \%$, mali przedsiębiorcy $30 \%$, średni przedsiębiorcy $30 \%$ i duże przedsiębiorstwa $20 \%$. W zależności od formy organizacyjno-prawnych w badaniu wzięło udział 20,5\% spółek jawnych, $18 \%$ spółdzielni, $12 \%$ spółek z ograniczoną odpowiedzialnością. Prawie $40 \%$ osób prowadziło działalność gospodarczą. Pozostała część badanych przedsiębiorstw reprezentowała pozostałe formy organizacyjno-prawne, włączając spółki komandytowe, komandytowo-akcyjne i akcyjne. Standing finansowy badanych przedsiębiorstw został oceniony z uwzględnieniem wskaźnika rentowności sprzedaży oraz subiektywnej oceny własnej sytuacji finansowej dokonanej w skali od 1 do 6 , gdzie 1 oznaczało bardzo złą sytuację finansowa, natomiast 6 - bardzo dobrą. W strukturze badanej populacji przedsiębiorstw uzyskano następujące grupy przedsiębiorstw w zależności od oceny sytuacji finansowej: przedsiębiorstwa oceniające swoją kondycje finansową jako bardzo dobrą $-5 \%$, dobrą $-46 \%$, dostateczną $-42,5 \%$ oraz niedostateczną, złą lub bardzo złą $-6,5 \%$.

Badane przedsiębiorstwa sektora zbożowego produkowały przeważnie pieczywo $(91,5 \%)$ oraz wyroby ciastkarskie $(75,0 \%)$ - tabela 1 . Ponad $2 / 3$ przedsiębiorstw wytwarzała produkty $\mathrm{z}$ dwóch kategorii produktowych $(68,0 \%)$, a z jednej ponad 1/4 firm. Wskazuje to na specyfikę rynków tych dwóch kategorii produktowych: pieczywa oraz wyrobów ciastkarskich. Są to rynki rozproszone, z firmami o zasięgu lokalnym, co jest związane ze specyfiką produktów i procesu technologicznego, wynika także z przyjętych systemów dystrybucji. Nie bez znaczenia jest postrzeganie pieczywa jako podstawowego produktu żywnościowego, co determinuje ugruntowane zwyczaje zakupowe.

\footnotetext{
${ }^{6}$ Szerzej w: H. Górska-Warsewicz, Ksztaltowanie architektury marek przedsiębiorstw sektora żywnościowego, Wyd. Difin, Warszawa 2011.
} 
Tabela 1

Pozycje asortymentowe wytwarzane przez przedsiębiorstwa sektora zbożowego

\begin{tabular}{|l|c|l|c|}
\hline Wyszczególnienie & Procent wskazań & Wyszczególnienie & Procent wskazań \\
\hline Ryż & 2,0 & Jedna & 26,5 \\
\hline Makaron & 3,0 & Dwie & 68,0 \\
\hline Pieczywo & 91,5 & Trzy & 5,0 \\
\hline Wyroby ciastkarskie & 75,0 & Cztery & 0,5 \\
\cline { 1 - 2 } Kasze i płatki & 2,5 & \multicolumn{2}{|l}{} \\
\cline { 1 - 2 } Mąka & 5,5 & \multicolumn{2}{|l}{} \\
\cline { 1 - 2 } & \multicolumn{2}{|l|}{} &
\end{tabular}

$\mathrm{N}=200$.

Źródło: Badania przedsiębiorstw sektora zbożowego, 11-12.2013 r.

Spośród badanych 200 przedsiębiorstw aż 70,5\% stanowiły firmy funkcjonujące na rynku powyżej 15 lat; znacznie rzadziej (15\%) odpowiedzi na pytania zadane w wywiadzie udzielały firmy funkcjonujące 10-15 lat. Najmniejszą grupę badanych stanowiły firmy funkcjonujące na rynku przetwórstwa zbóż 5-9 lat $(5 \%)$ oraz poniżej 5 lat $(9,5 \%)$. Badane przedsiębiorstwa posiadały głównie kapitał polski (98\%); zaledwie 1,5\% podmiotów zadeklarowało mieszaną formę własności. W strukturze kapitałowej tylko jednego przedsiębiorstwa dominował kapitał zagraniczny.

\section{Rozwój nowych produktów w badanych przedsiębiorstwach}

Wprowadzanie na rynek nowych produktów w największym stopniu dotyczyło pieczywa, na ten fakt wskazało prawie $90 \%$ badanych przedsiębiorstw sektora zbożowego (tab. 2). Prawie $2 / 3$ firm wprowadzało nowe produkty w kategorii wyroby ciastkarskie. Taki rozkład odpowiedzi wynika ze specyfiki tych kategorii produktowych cechujących się dużym zróżnicowaniem składu surowcowego, stosowanych dodatków smakowych, kształtów produktów, sposobu konfekcjonowania i wielkości opakowania. Możliwości różnicowania produktów w tych dwóch kategoriach produktowych determinowany był chęcią zwiększenia atrakcyjności oferty produktowej, zwiększenia konkurencyjności firmy i dopasowania wytwarzanych produktów do potrzeb, preferencji i upodobań konsumentów.

Największa średnia liczba wprowadzanych nowych produktów dotyczyła dwóch kategorii produktowych: pieczywa i wyrobów ciastkarskich. Jest to konsekwencją rozwoju nowych produktów w tych kategoriach produktowych, wynikających z możliwości wprowadzenia modyfikacji technologicznych przy 


\section{Tabela 2}

Fakt wprowadzenia nowych produktów w przedsiębiorstwach sektora zbożowego w zależności od kategorii produktowej

\begin{tabular}{|l|c|}
\hline Wyszczególnienie & Procent wskazań \\
\hline Ryż & 2,0 \\
\hline Makaron & 3,0 \\
\hline Pieczywo & 89,5 \\
\hline Wyroby ciastkarskie & 65,5 \\
\hline Kasze i płatki & 2,5 \\
\hline Mąka & 5,5 \\
\hline
\end{tabular}

$\mathrm{N}=200$.

Źródło: Badania przedsiębiorstw sektora zbożowego, 11-12.2013 r.

stosunkowo niewysokich dodatkowych kosztach. Wyższa średnia liczba nowości pozycji asortymentowych w kategorii produktowej wyroby ciastkarskie wynikała $\mathrm{z}$ większej różnorodności tej kategorii w porównaniu do pieczywa ze względu na możliwość zastosowania dodatków smakowych.

\section{Tabela 3}

Średnia liczba nowości pozycji asortymentowych w przedsiębiorstwach sektora zbożowego w zależności od kategorii produktowej

\begin{tabular}{|l|c|}
\hline Wyszczególnienie & $\begin{array}{c}\text { Średnia liczba nowości pozycji } \\
\text { asortymentowych }\end{array}$ \\
\hline Ryż & 1,75 \\
\hline Makaron & 5,17 \\
\hline Pieczywo & 7,89 \\
\hline Wyroby ciastkarskie & 8,60 \\
\hline Kasze i płatki & 3,60 \\
\hline Mąka & 3,36 \\
\hline
\end{tabular}

Jako $100 \%$ przyjęto firmy wprowadzające nowe produkty na rynek: $\mathrm{N}($ ryż $)=4, \mathrm{~N}$ (makaron) $=$ $=6, \mathrm{~N}($ pieczywo $)=179, \mathrm{~N}($ wyroby ciastkarskie $)=131, \mathrm{~N}($ kasze i płatki $)=5, \mathrm{~N}($ mąka $)=11$.

Źródło: Badania przedsiębiorstw sektora zbożowego, 11-12.2013 r.

\section{Oczekiwania przedsiębiorstw wobec promocji w kontekście nowych produktów}

Oczekiwana skuteczność promocji w przedsiębiorstwach sektora zbożowego była największa w przypadku reklamy w miejscu sprzedaży (średnia 4,33 w skali od 1 do 5 , gdzie 1 oznacza działanie nieskuteczne, a 5 bardzo skuteczne), promocji cenowych $(4,14)$, promocji sprzedaży $(4,11)$ oraz degustacji $(4,09)$ - tabela 4. 
Tabela 4

Oczekiwana skuteczność wybranych form promocji w przedsiębiorstwach sektora zbożowego

\begin{tabular}{|c|c|c|c|c|c|c|c|c|}
\hline \multirow[b]{2}{*}{ Wyszczególnienie } & \multirow[b]{2}{*}{ 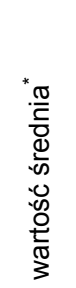 } & \multicolumn{5}{|c|}{ Struktura procentowa odpowiedzi [\%] } & \multirow[b]{2}{*}{ 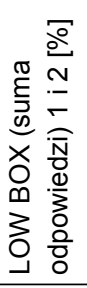 } & \multirow[b]{2}{*}{ 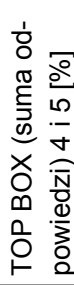 } \\
\hline & & 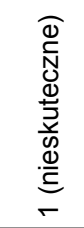 & 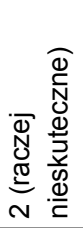 & 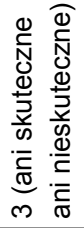 & 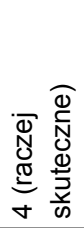 & 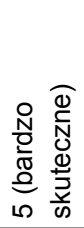 & & \\
\hline Reklama w mediach & 2,95 & 22,5 & 13,5 & 28,0 & 19,0 & 17,0 & 36,0 & 36,0 \\
\hline Reklama w miejscu sprzedaży & 4,33 & 1,5 & 2,0 & 12,0 & 31,0 & 53,5 & 3,5 & 84,5 \\
\hline $\begin{array}{l}\text { Reklama zewnętrzna (billboardy, } \\
\text { tablice) }\end{array}$ & 3,49 & 10,0 & 9,0 & 26,5 & 31,5 & 23,0 & 19,0 & 54,5 \\
\hline Sponsoring & 3,05 & 16,5 & 12,0 & 37,0 & 19,0 & 15,5 & 28,5 & 34,5 \\
\hline Public Relations & 2,92 & 19,0 & 14,5 & 34,5 & 20,0 & 12,0 & 33,5 & 32,0 \\
\hline Targi, pokazy, wystawy & 3,26 & 14,0 & 11,5 & 29,0 & 26,0 & 19,5 & 25,5 & 45,5 \\
\hline Opakowania promocyjne & 3,75 & 8,0 & 7,0 & 17,5 & 37,0 & 30,5 & 15,0 & 67,5 \\
\hline Degustacje & 4,09 & 3,5 & 5,0 & 12,5 & 37,5 & 41,5 & 8,5 & 79,0 \\
\hline Reklama bezpośrednia & 3,38 & 13,5 & 10,0 & 26,5 & 25,0 & 25,0 & 23,5 & 50,0 \\
\hline Promocja sprzedaży & 4,11 & 2,0 & 2,5 & 15,5 & 42,5 & 37,5 & 4,5 & 80,0 \\
\hline Promocje cenowe & 4,14 & 4,0 & 2,5 & 12,5 & 37,5 & 43,5 & 6,5 & 81,0 \\
\hline Sprzedaż osobista & 3,49 & 11,5 & 5,0 & 30,5 & 29,0 & 24,0 & 16,5 & 53,0 \\
\hline Zwiększenie marży & 2,92 & 18,5 & 10,5 & 42,0 & 18,5 & 10,5 & 29,0 & 29,0 \\
\hline Rabaty & 3,71 & 5,5 & 5,5 & 24,5 & 41,5 & 23,0 & 11,0 & 64,5 \\
\hline $\begin{array}{l}\text { Premiowanie najlepszych } \\
\text { sprzedawców }\end{array}$ & 3,78 & 7,0 & 6,5 & 20,5 & 34,0 & 32,0 & 13,5 & 66,0 \\
\hline Pomoc przy ekspozycji towarów & 3,63 & 7,5 & 7,5 & 23,0 & 39,0 & 23,0 & 15,0 & 62,0 \\
\hline Odroczone terminy płatności & 3,43 & 9,0 & 8,5 & 34,0 & 28,0 & 20,5 & 17,5 & 48,5 \\
\hline
\end{tabular}

${ }^{*} \mathrm{~N}=200$; odpowiedzi w skali od 1 do 5 , gdzie 1 oznacza nieskuteczne, a 5 - najbardziej skuteczne.

Źródło: Badania przedsiębiorstw sektora zbożowego, 11-12.2013 r.

Wskaźnik odpowiedzi „skuteczne” i „bardzo skuteczne” był w przypadku tych form promocji najwyższy i wynosił od 79 do 84,5\%. Najniższe średnie wyniki uzyskały takie formy promocji jak public relations i zwiększenie marży $(2,92)$ oraz reklama w mediach $(2,95)$; w przypadku tych samych form promocji odsetek odpowiedzi ,nieskuteczne” i ,raczej nieskuteczne” był najwyższy (od 29 do 36\%). Świadczy to o zadowoleniu podmiotów z obecnej skuteczności wykorzystywanych form promocji lub wynika z braku oczekiwań co do znaczących zmian w tym zakresie. 


\section{Oczekiwania wobec marki w kontekście rozwoju nowych produktów}

Znaczenie marki produktowej dla przedsiębiorstw sektora zbożowego w największym stopniu dotyczyło utrzymania dotychczasowych konsumentów (średnia 4,39 w skali od 1 do 5, gdzie 1 oznacza całkowicie się nie zgadzam, a 5 - całkowicie się zgadzam). Należy to powiązać z funkcjami marki postrzeganymi przez konsumentów odnoszącymi się do gwarancji jakości wyrobu finalnego, składników użytych oraz procesu technologicznego. Nie bez znaczenia jest stałość składu produktowego, w rozumieniu otrzymywania zawsze wyrobów o takich samych parametrach fizyko-chemicznych oraz właściwościach organoleptycznych. Istotne dla konsumentów jest również funkcja identyfikacyjna oraz ułatwiająca codzienne zakupy.

Na drugim miejscu wśród oczekiwań wobec marki produktów zbożowych w opinii przedstawicieli przedsiębiorstw zbożowych uplasowały się stwierdzenia dotyczące rozwoju firmy, zapewnienia większej sprzedaży oraz możliwości pozyskania nowych konsumentów (średnia powyżej 4). Należy wskazać również na ułatwione działania w zakresie konkurowania na rynku (średnia 4,02).

Spośród badanych oczekiwań w najmniejszym stopniu zwracano uwagę na ograniczenie ryzyka rynkowego oraz ułatwienie współpracy z sieciami detalicznymi, co należy wiązać z charakterem badanych kategorii produktowych, praktyką dystrybucji, strukturą rynku oraz istniejącymi przyzwyczajeniami konsumenckimi (tab. 5).

\section{Tabela 5}

Oczekiwania wobec marki produktów zbożowych

\begin{tabular}{|c|c|c|c|c|c|c|c|c|}
\hline \multirow[b]{2}{*}{ Wyszczególnienie } & \multirow[b]{2}{*}{ 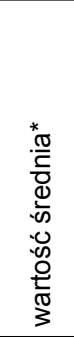 } & \multicolumn{5}{|c|}{$\begin{array}{c}\text { Struktura procentowa odpowiedzi } \\
{[\%]}\end{array}$} & \multirow[b]{2}{*}{ 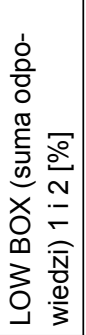 } & \multirow[b]{2}{*}{ 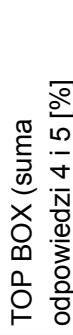 } \\
\hline & & 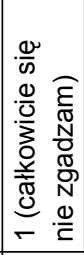 & 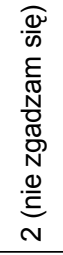 & 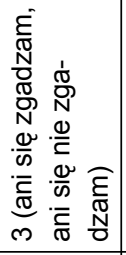 & $\begin{array}{l}\widehat{.0} \\
\text { N } \\
E \\
\mathbb{N} \\
\mathbb{D} \\
\mathbb{N} \\
\mathbb{N} \\
\forall\end{array}$ & 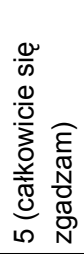 & & \\
\hline Ogranicza ryzyko rynkowe & 3,72 & 4,0 & 6,0 & 31,0 & 32,5 & 26,5 & 10,0 & 59,0 \\
\hline Zapewnia większą pewność sprzedaży & 4,15 & 0,0 & 3,0 & 17,0 & 42,0 & 38,0 & 3,0 & 80,0 \\
\hline Ułatwia konkurencję z innymi firmami & 4,02 & 2,0 & 3,5 & 21,5 & 36,5 & 36,5 & 5,5 & 73,0 \\
\hline Ułatwia zdobycie nowych konsumentów & 4,19 & 1,0 & 2,5 & 18,0 & 33,5 & 45,0 & 3,5 & 78,5 \\
\hline $\begin{array}{l}\text { Ułatwia utrzymanie dotychczasowych } \\
\text { konsumentów }\end{array}$ & 4,39 & 0,0 & 1,0 & 11,5 & 35,5 & 52,0 & 1,0 & 87,5 \\
\hline Ułatwia współpracę z sieciami detalicznymi & 3,80 & 8,0 & 3,0 & 25,0 & 29,5 & 34,5 & 11,0 & 64,0 \\
\hline Gwarantuje rozwój firmy & 4,30 & 0,0 & 1,5 & 15,5 & 34,5 & 48,5 & 1,5 & 83,0 \\
\hline
\end{tabular}

*Odpowiedzi w skali od 1 do 5 , gdzie 1 oznacza całkowicie się nie zgadzam, a 5 - całkowicie się zgadzam.

$\mathrm{N}=200$.

Źródło: Badania przedsiębiorstw sektora zbożowego, 11-12.2013 r. 


\section{Podsumowanie i wnioski}

Funkcjonowanie przedsiębiorstw sektora zbożowego w zmiennych warunkach otoczenia rynkowego wymusza konieczność podejmowania odpowiednich działań w zakresie promocji oraz marki produktów. Badane przedsiębiorstwa organizowały procesy komunikacji rynkowej w sposób tradycyjny, z zachowaniem dotychczasowych rozwiązań organizacyjnych. Wyrażało się to w stosowaniu określonych metod promocji cenowej, promocji w miejscu sprzedaży czy degustacji, a w mniejszym stopniu reklamy w mediach. Większość badanych podmiotów gospodarczych to firmy długo działające na rynku krajowym; może to być przyczyną zadowolenia firm z obecnie stosowanych form promocji, ale również niemożnością realistycznej oceny działań promocyjnych, będących poza zasięgiem (przede wszystkim finansowym) przedsiębiorstwa. Kolejnym powodem może być potrzeba stosowania narzędzi prosprzedażowych (takich jak promocja sprzedaży czy promocje cenowe) w znacznie większym stopniu niż prowizerunkowych, co nie jest zjawiskiem pozytywnym, powoduje bowiem nastawienie się przedsiębiorstwa przede wszystkim na zyski w krótszej perspektywie czasowej.

Proces zarządzania markami w przedsiębiorstwach sektora zbożowego determinowany jest specyfiką technologii żywności, ewolucją zachowań konsumenckich oraz zróżnicowaniem - pod względem ilościowym i jakościowym - oferty rynkowej. Właściwie zaplanowany proces budowy marek powinien stać się warunkiem koniecznym dla przedsiębiorstw oferujących produkty o coraz większym zróżnicowaniu technologicznym, kierowanych do różnych grup odbiorców oraz realizujących różne programy marketingowe.

Znaczenie marki produktowej dla przedsiębiorstw sektora zbożowego w największym stopniu dotyczyło utrzymania dotychczasowych konsumentów. Należy to powiązać z funkcjami marki postrzeganymi przez konsumentów i odnoszącymi się do gwarancji jakości wyrobu finalnego, składników użytych oraz procesu technologicznego. Nie bez znaczenia jest stałość składu produktowego, w rozumieniu otrzymywania zawsze wyrobów o takich samych parametrach fizyko-chemicznych oraz właściwościach organoleptycznych. Należy zwrócić także uwagę na znaczenie marki w kontekście zaufania konsumenta do produktu i przedsiębiorstwa, które tę markę stosuje. Warunkiem powstania tego zaufania może być symboliczna (psychologiczna) satysfakcja lub spełniana przez markę funkcja gwarancji jakości produktu.

Reasumując, należy stwierdzić, że scharakteryzowane uwarunkowania marketingowe dotyczą przedsiębiorstw sektora produktów i przetworów zbożowych w poszczególnych segmentach oraz jako całości. Dostępne badania zachowań odbiorców rynkowych (nabywców i konsumentów) tych produktów, na tle ich potrzeb i warunków rynku, mogą dać wiedzę potrzebną dla wyboru odpowied- 
nich działań marketingowych $\mathrm{w}$ zakresie promocji i marki w poszczególnych segmentach rynku ${ }^{7}$. Brak jest jednak pełnej informacji na temat działań promocyjnych oraz strategii marki prowadzonych przez poszczególne przedsiębiorstwa specjalizujące się $\mathrm{w}$ produkcji wyrobów w wyodrębnionych segmentach tego sektora i rynku. Szczególnie dotyczy to małych i średnich przedsiębiorstw dominujących w kilku segmentach tego sektora (rynku). Wytwarzają one produkty najczęściej na niewielką skalę na rozproszonym rynku odbiorców, dlatego ich działania promocyjne są prowadzone często lokalnie, na małą skalę, albo też przyjmują postać promocji towarowej. Stosowane rozwiązania wobec marek powinny zostać zintensyfikowane dla zapewnienia stabilności sprzedaży i konkurowania wartością dodaną bazującą na marce. Wymaga to zatem podjęcia dalszych szczegółowych badań w zakresie stosowania odpowiednich narzędzi i strategii promocji w kontekście znaczenia marki i kształtowania konkurencyjności produktów zbożowych w oparciu o wartość dodaną.

\section{Literatura}

AAKER D.A., 1996: Building Strong Brands, New York: Free Press.

AMBLER T., STYLES C., 1997: Brand development versus new product development: toward a process model of extension decisions, Journal of Product and Brand Management, vol. 6, No. 4, s. 222-234.

BELCH G.E., BELCH M.A., 1995: Introduction to Advertising and Promotion, Irwin, Chicago.

BIVAINIENE L., 2007: Brand Image Conceptualization: The Role of Marketing Communication, Economics and Management, vol. 12, No. 2.

CZARNECKI A., 2004: Strategie komunikacji marketingowej, [w:] W. Wrzosek (red.), Strategie marketingowe, PWE, Warszawa, s. 175-199.

DAVIDSON H., 1997: Even more offensive marketing, Penguin, London.

deCHERNATONY L., 2003: Marka. Wizja i tworzenie marki, GWP, Gdańsk.

Dictionary of Marketing Terms, AMA Chicago 1995, s. 18, cyt. za J. Altkorn, 1999: Strategia marki, PWE, Warszawa.

GÓRSKA-WARSEWICZ H., 2011: Ksztaltowanie architektury marek przedsiębiorstw sektora żywnościowego, Wyd. Difin, Warszawa.

GÓRSKA-WARSEWICZ H., ŚWIĄTKOWSKA M., KRAJEWSKI K., 2009: Model zintegrowanej komunikacji rynkowej. Aspekty zarzqdzania produktem i marka na rynku żywności, Wyd. SGGW, Warszawa.

\footnotetext{
${ }^{7}$ Patrz także w: Kociszewski M., Szwacka-Mokrzycka J., 2011: Uwarunkowania rozwoju przemystu spożywczego po przystapieniu Polski do UE, Zeszyty Naukowe SGGW w Warszawie - Problemy Rolnictwa Światowego 2011, t. 11 (26): 67-77; Grębowiec M., 2011: Znaczenie innowacji produktowych $w$ rozwoju przedsiębiorstw na przykładzie branży owocowo-warzywnej, Zeszyty Naukowe SGGW w Warszawie - Problemy Rolnictwa Światowego 2011, t. 11 (26): 36-46.
} 
GÓRSKA-WARSEWICZ H., ŚWIĄTKOWSKA M., KRAJEWSKI K., 2013: Marketing żywności, Wolters Kluwer, Warszawa.

GÓRSKA-WARSEWICZ H., 2011: Konsumencki kapitał marek produktów na potrzeby zarzadzania przedsiębiorstwem (na przyktadzie sektora mleczarskiego), Wydawnictwo Naukowe Wydziału Zarządzania Uniwersytetu Warszawskiego, Warszawa.

GRĘBOWIEC M., 2011: Znaczenie innowacji produktowych $w$ rozwoju przedsiębiorstw na przykładzie branży owocowo-warzywnej, Zeszyty Naukowe SGGW w Warszawie - Problemy Rolnictwa Światowego 2011, t. 11 (26): 36-46.

KALL J., 2002: Reklama. PWE, Warszawa.

KAPFERER J.N., 2009: The new strategic Brand Management. Creating and Sustaining Brand Equity Long Term, Kogan Page $4^{\text {th }}$ ed., London and Philadelphia.

KELLER K.L., 1993: Conceptualizing, measuring and managing customer-based brand equity, Journal of Marketing, vol. 57, s. 1-22.

KOCISZEWSKI M., SZWACKA-MOKRZYCKA J., 2011: Uwarunkowania rozwoju przemystu spożywczego po przystapieniu Polski do UE, Zeszyty Naukowe SGGW w Warszawie - Problemy Rolnictwa Światowego 2011, t. 11 (26): 67-77.

KOTLER PH., ARMSTRONG G., SAUNDERS J., WONG V., 2002: Marketing. Podręcznik europejski, PWE, Warszawa.

KOTLER PH., 2005: Marketing, Dom Wydawniczy Rebis, Poznań.

KOWALSKA M., 2007: Zyskać przewagę. Zintegrowana komunikacja w nowoczesnym marketingu. Między teoriq a praktyka, Adam Marszałek, Toruń.

KRAMER T., 2004: Podstawy marketingu, PWE, Warszawa.

LEUTHESSER L., 1988: Defining, Measuring, and Managing Brand Equity, Conference Summary (Cambridge, MA: Marketing Science Institute).

RYDEL M., 2001: Komunikacja jako element marketingu, [w:] M. Rydel (red.), Komunikacja marketingowa, Ośrodek Doradztwa i Doskonalenia Kadr Sp. z o.o., Gdańsk, s. 15-40.

SRIVASTAVA R.K., SHOCKER A., 1991: Brand Equity:A Perspective on Its Meaning and Measurement, Technical Working Paper, Cambridge, MA: Marketing Science Institute.

STYLES C., AMBLER T., 1995: Brand management [w:] Crainer S. (ed.) Financial Times Handbook of Management, Pitman, London, s. 581-593.

ŚWIĄTKOWSKA M., GÓRSKA-WARSEWICZ H., KRAJEWSKI K., 2010: Zarzadzanie komunikacja rynkowa przedsiębiorstw - organizacja, strategie, uwarunkowania, Wyd. SGGW, Warszawa.

URBANEK G., 2002: Zarzqdzanie markq, PWE, Warszawa.

VAZQUEZ R., del RIO A.B., IGLESIAs V., 2002: Consumer-based Brand Equity: Development and Validation of a Measurement Instrument, Journal of Marketing Management 2002, vol. 18, No. 1\&2, s. 29.

WIKTOR J.W., 2006: Promocja. System komunikacji przedsiębiorstwa z rynkiem, PWN, Warszawa. 


\begin{abstract}
Abstrakt
Celem opracowania była analiza wybranych uwarunkowań marketingowych determinujących wprowadzanie na rynek nowych produktów w przedsiębiorstwach sektora zbożowego, ze szczególnym uwzględnieniem działań promocyjnych i marki. Badania empiryczne w postaci wywiadów telefonicznych ze wspomaganiem komputerowym zrealizowano w ramach projektu POIG.01-14-041/12 współfinansowanego z Europejskiego Funduszu Rozwoju Regionalnego. Próbę badawczą stanowiło 200 przedsiębiorstw dobranych według kryterium wielkości przedsiębiorstw. Zastosowano następującą strukturę przedsiębiorstw: mikroprzedsiębiorcy $20 \%$, mali przedsiębiorcy $30 \%$, średni przedsiębiorcy $30 \%$ i duże przedsiębiorstwa $20 \%$.

W niniejszym opracowaniu wykorzystano część wyników w zakresie marketingowych uwarunkowań wprowadzania nowych produktów w przedsiębiorstwach sektora zbożowego. Wprowadzanie na rynek nowych produktów w największym stopniu dotyczyło pieczywa, na ten fakt wskazało prawie $90 \%$ badanych przedsiębiorstw sektora zbożowego. Oczekiwana skuteczność promocji w przedsiębiorstwach sektora zbożowego była największa w przypadku reklamy w miejscu sprzedaży, promocji cenowych, promocji sprzedaży oraz degustacji. Znaczenie marki produktowej dla przedsiębiorstw sektora zbożowego w największym stopniu dotyczyło utrzymania dotychczasowych konsumentów, rozwoju firmy, zapewnienia większej sprzedaży oraz możliwości pozyskania nowych konsumentów.
\end{abstract}

Słowa kluczowe: rozwój nowych produktów, uwarunkowania marketingowe, promocja, marka

\title{
Marketing Determinants of New Products Development in Cereals Sector Companies
}

\section{Abstract}

The aim of this study was to analyze selected marketing conditions of introducing new products into market in cereals sector companies. Special attention was given to promotional and branding activities. Empirical research was conducted via computer assisted telephone interviews in project POIG.01-14-041/12 of European Regional Development Fund. The research sample of 200 companies was selected due to the size of companies: $20 \%$ of the sample were micro-companies, $30 \%$ small companies, $30 \%$ medium size companies, and $20 \%$ large companies. 
This study refers to the data concerning the marketing determinants of new products development and introduction into market in the cereals sector. Introducing new products concerned mostly bread and the like $-90 \%$ of the companies stated so. The highest expected effectiveness of promotional activities was noticed in the case of advertising in purchasing places, price promotion and degustation. The brand was the most important from the point of view of maintaining consumers, company development, improving sales, as well as possibilities of gaining new consumers.

Key words: new product development, marketing conditions, promotion, brand 